\title{
Sferositosis Herediter: laporan kasus
}

\author{
Teny Tjitra Sari, Ismi Citra Ismail \\ Departemen Ilmu Kesehatan Anak RS Cipto Mangunkusumo Jakarta
}

\begin{abstract}
Sferositosis herediter $(\mathrm{SH})$ merupakan salah satu jenis anemia hemolitik yang disebabkan defek molekular pada satu atau lebih protein sitoskleletal sel darah merah. Diagnosis SH sulit untuk ditegakkan karena tidak ada tanda atau gejala yang patognomonik. Seorang bayi laki-laki, usia 5 bulan datang dirujuk seorang dokter spesialis anak dengan dugaan talasemia dan riwayat batuk dan pilek, demam yang tidak terlalu tinggi, kurang aktif, dan didapatkan kadar hemoglobin (Hb) 6,4 g/dL. Diagnosis sferositosis herediter ditegakkan berdasarkan adanya riwayat kuning saat neonatus, anemia, splenomegali, ditemukannya sferosit yang banyak pada pemeriksaan darah tepi, dan analisis protein membran eritrosit menunjukkan defisiensi spektrin alfa. Pasien diberi asam folat dan transfusi darah. Splenektomi belum terindikasi karena anemia masih dapat dikompensasi oleh sumsum tulang. (Sari Pediatri 2009;11(4):298-304).
\end{abstract}

Kata kunci: anemia hemolitik, sferositosis, fragilitas osmotik

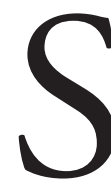
ferositosis herediter $(\mathrm{SH})$ merupakan salah satu jenis anemia hemolitik yang disebabkan oleh kerusakan pada membran eritrosit. Kerusakan terjadi sebagai akibat defek molekular pada satu atau lebih protein sitoskleletal sel darah merah yang terdiri dari spektrin, ankirin, band 3 protein, dan protein 4.2. ${ }^{1}$ Sferositosis merupakan jenis anemia hemolitik yang paling sering dijumpai di Eropa dengan insidens 1 kasus per 5000 jiwa. Hingga saat ini belum tersedia data epidemiologi SH di Indonesia. Rekam medis Poliklinik Departemen Ilmu Kesehatan Anak RSCM belum mencatat pasien dengan diagnosis $\mathrm{SH}$. Lembaga Biologi Molekular Eijkman menemukan 12

\footnotetext{
Alamat korespondensi

Dr. Teny Tjitra Sari, SpA. Divisi Hematologi Onkologi Departemen Ilmu Kesehatan Anak FKUI- RSCM Jl. Salemba no. 6, Jakarta 10430. Telepon: 021-3907744, 31901170 Fax.021-3913982.
}

pasien yang terbukti SH sejak tahun 2002 sampai 2008. Gejala klinis SH dapat berupa anemia ringan sampai berat disertai ikterus dan splenomegali. Diagnosis SH cukup sulit untuk ditegakkan karena tidak ada tanda atau gejala patognomonik. ${ }^{1,2}$ Tujuan laporan kasus untuk membahas diagnosis sferositosis herediter.

\section{Kasus}

Seorang bayi laki-laki, usia 5 bulan, dirujuk seorang dokter spesialis anak dengan keterangan dugaan talasemia. Dua minggu sebelum datang ke RS Dr. Cipto Mangunkusumo Jakarta (RSCM), terdapat keluhan batuk dan pilek, demam yang tidak terlalu tinggi. Frekuensi minum susu pasien agak berkurang dan pasien terlihat kurang aktif. Pada pemeriksaan laboratorium didapatkan kadar hemoglobin ( $\mathrm{Hb}$ ) 6,4 $\mathrm{g} / \mathrm{dL}$ dan kemudian dirujuk ke RSCM. Saat berusia 
2 hari pasien tampak kuning dengan kadar bilirubin $20 \mathrm{mg} / \mathrm{dL}$ sehingga pasien mendapatkan terapi sinar dan dirawat selama 10 hari. Tidak ada anggota keluarga lain yang mengalami gejala serupa atau sering mendapat transfusi. Pasien merupakan anak kedua dari dua bersaudara. Ayah berusia 36 tahun, suku Jawa; ibu berusia 31 tahun, suku Jawa. Tidak ada riwayat konsanguinitas pada orangtua pasien.

Pada pemeriksaan fisis awal didapatkan keadaan pasien sadar dan tanda vital baik. Konjungtiva pucat, dan sklera tidak ikterik. Hasil pemeriksaan jantung dan paru dalam batas normal. Abdomen tampak datar, teraba lemas, hati dan limpa tidak teraba. Akral teraba hangat, perfusi perifer normal, telapak tangan tampak pucat. Pada pemeriksaan darah tepi lengkap saat kunjungan pertama didapatkan kadar $\mathrm{Hb} 8,1$ $\mathrm{g} / \mathrm{dL}$, hematokrit (Ht) $23,9 \%$, leukosit $11.500 / \mu \mathrm{L}$, $\mathrm{dan}$ trombosit $598.000 / \mu \mathrm{L}$. Mean corpuscular volume (MCV) 76,5 fL, mean corpuscular hemoglobin $(\mathrm{MCH})$ $25,9 \mathrm{pg}$, mean cell hemoglobin concentration (MCHC) $33,9 \mathrm{~g} / \mathrm{dL}$, red cell distribution width (RDW) $34,4 \%$. Hitung jenis leukosit (\%) basofil 0, eosinofil 0, batang 0 , segmen 40, limfosit 56 , dan monosit 4. Diagnosis kerja pada saat masuk dirawat adalah tersangka talasemia dan pemeriksaan analisis hemoglobin, $\mathrm{HbF}$ 9,1\% (normal 2,3-13\%) dan HbA 2,4\% (normal 1,9-3,5\%).

Gambaran darah tepi menunjukkan sel darah merah mikrositik hipokrom, anisositosis, dan tampak sferosit. Diagnosis banding adalah talasemia, sferositosis herediter, dan kelainan membran eritrosit lainnya. Pemeriksaan lebih lanjut di Lembaga Eijkman didapatkan $\mathrm{Hb} 7,1 \mathrm{~g} / \mathrm{dL}$, MCV 72,5 fL, $\mathrm{MCH} 26,2 \mathrm{pg}$, MCHC 36,2 g/dL, RDW 33,1\%, $\mathrm{HbA}_{2}$ 2,7\% dan $\mathrm{HbF} 9 \%$ dan morfologi darah merah anisositosis, banyak terlihat sel gelap sferosit, sel mikrositik hipokrom, makrositik polikrom, dan retikulositosis. Hasil pemeriksaan indeks eritrosit dan analisis $\mathrm{Hb}$ sesuai dengan sferositosis herediter, anemia hemolitik autoimun, dan masih mungkin talasemia alfa. Orangtua pasien dianjurkan untuk melakukan skrining talasemia.

Hasil pemeriksaan penunjang lainnya yaitu SI $152 \mu \mathrm{g} / \mathrm{dL}$ (normal 60-160 $\mu \mathrm{g} / \mathrm{dL}$ ), TIBC $430 \mu \mathrm{g} / \mathrm{dL}$ (normal $250-430 \mu \mathrm{g} / \mathrm{dL}$ ), feritin 180,8 ng/dL (normal $13-150 \mathrm{ng} / \mathrm{dL}$ ) dan saturasi transferin 35,35\%. Hasil uji Coombs negatif, uji fragilitas osmotik (resistensi $\mathrm{NaCl}$ ) positif dan analisis protein membran eritrosit menunjukkan defisiensi spektrin alfa. Kedua orangtua pasien tidak terbukti membawa sifat talasemia. Pemeriksaan aspirasi sumsum tulang menunjukkan hiperaktif eritropoesis dan retikulositosis (20\%). Diagnosis ditegakkan sferositosis herediter. Pasien diberi asam folat $2 \times 2,5 \mathrm{mg}$ dan vitamin E $2 \times 100$ UI. Saat ini pasien kontrol teratur di RSCM. Pertumbuhan dan perkembangan pasien dalam batas normal, limpa membesar (Schuffner I). Kadar hemoglobin pasien berkisar antara 6,2-9,3 g/dL dan telah diberikan transfusi sebanyak tiga kali.

\section{Diskusi}

Sebagian besar kasus SH diturunkan secara autosomal dominan, namun 25\% kasus disebabkan oleh mutasi spontan atau diturunkan secara resesif. ${ }^{1}$ Mutasi spontan enam kali lebih sering dibandingkan dengan SH penurunan secara autosomal resesif. Konseling genetik disarankan bagi orangtua dengan anak $\mathrm{SH}$ non-dominan. ${ }^{3}$

Membran eritrosit terdiri atas lapisan lemak dan protein yang saling berinteraksi. Lapisan protein pada membran eritrosit dibedakan menjadi dua kelompok besar yaitu protein integral dan protein perifer. Protein integral melekat pada lapisan lemak membran sel karena interaksi hidrofobik. Glikoporin dan band 3

Tabel 1. Klasifikasi sferositosis herediter ${ }^{8,9}$

\begin{tabular}{lccc}
\hline Klasifikasi & Ringan & Sedang & Berat \\
\hline Insidens (\%) & $20-30$ & $50-60$ & $5-7$ \\
Hb (g/dL) & $11-15$ & $8-12$ & $6-8$ \\
Retikulosit (\%) & $3-6$ & $>6$ & $>10$ \\
Bilirubin (mg/dL) & $1-2$ & $>2$ & $>3$ \\
Transfusi darah & Tidak & Kadang diperlukan & Rutin \\
Splenektomi & Biasanya tidak diperlukan & Kadang diperlukan & Ya \\
\hline
\end{tabular}

Sari Pediatri, Vol. 11, No. 4, Desember 2009 


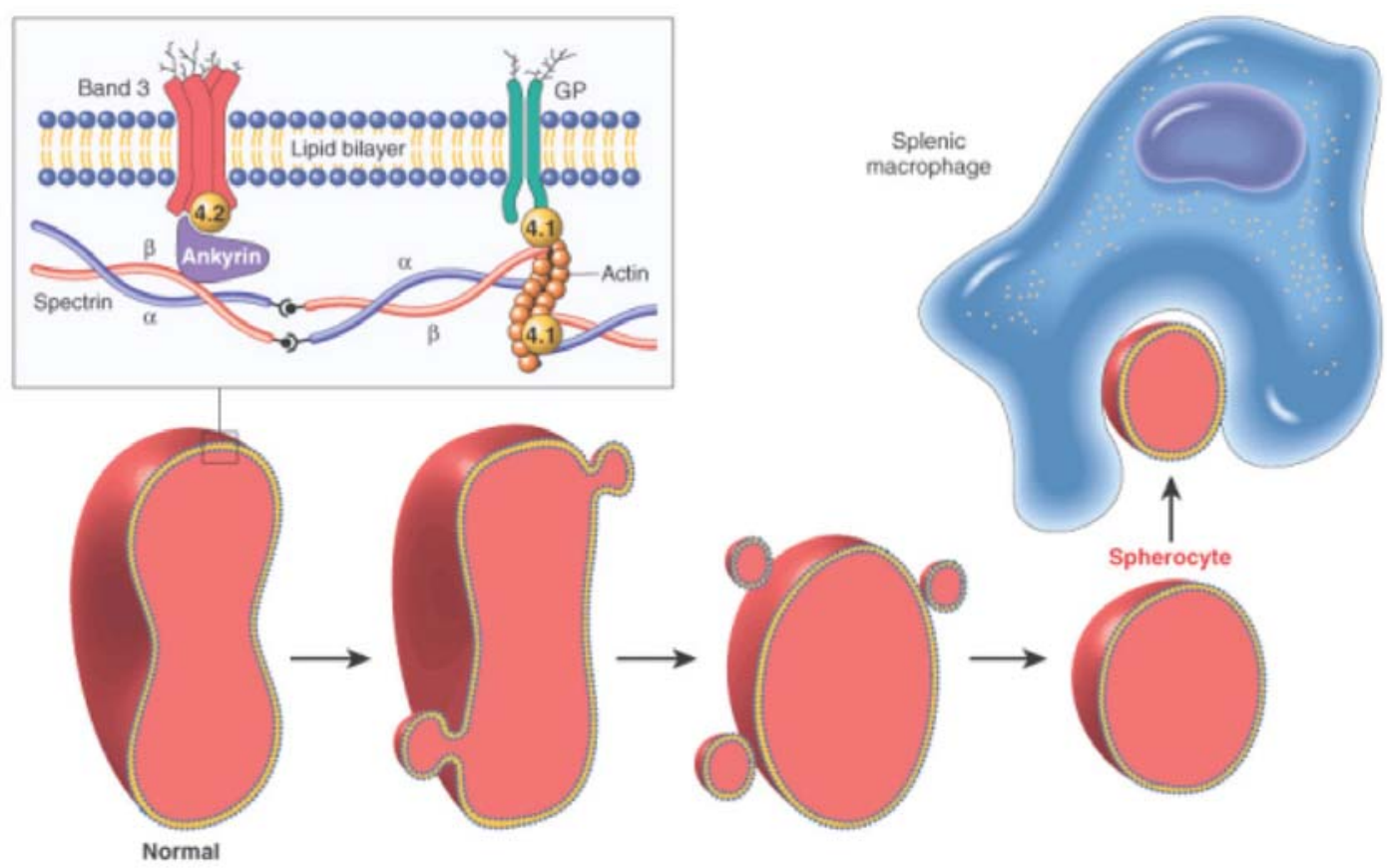

Gambar 1. Sitoskeleton membran sel darah merah dan perubahannya menjadi sferositosis. ${ }^{6}$

protein adalah protein terbanyak dalam kelompok ini. Protein perifer disebut juga protein sitoskeletal, terdapat dalam sitoplasma dari lapisan lemak membran eritrosit. Protein perifer terdiri atas spektrin, aktin, protein 4.1 , protein 4.2 (palidin), ankirin, adusin, tropomiosin, dan tropomodulin. ${ }^{4}$

Defek selular primer pada $\mathrm{SH}$ adalah berkurangnya luas permukaan membran relatif terhadap volume intraselular sel eritrosit. Sehingga menyebabkan bentuk sel menjadi bulat dan deformabilitas sel berkurang (Gambar 1)., ${ }^{5,6}$ Selain itu, defek protein pada membran sel meningkatkan fragilitas membran sehingga sel menjadi mudah lisis terutama di limpa. Limpa memiliki $\mathrm{pH}$ dan kadar glukosa yang rendah serta kadar toksin radikal bebas yang tinggi yang dapat menyebabkan kerusakan pada membran eritrosit. ${ }^{2}$

Defek molekular yang terjadi pada $\mathrm{SH}$ adalah defisiensi spektrin, ankirin, band 3 protein atau palidin pada membran sel. Kualitas dan kuantitas membran eritrosit pasien $\mathrm{SH}$ berkurang karena defisiensi protein-protein tersebut. Defisiensi ankirin terbanyak ditemukan pada kasus SH di Eropa dan Amerika, sedangkan di Jepang defek terbanyak ditemukan pada band 3 protein dan palidin. ${ }^{1,2,7}$ Pada SH yang diturunkan secara non-dominan pada umumnya defek terjadi pada spektrin alfa dan palidin. ${ }^{2}$
Pasien ini mengalami defisiensi spektrin alfa pada membran eritrosit. Hasil pemeriksaan analisis $\mathrm{Hb}$ kedua orangtua pasien normal, sesuai dengan $\mathrm{SH}$ non-dominan. Namun belum dapat dibedakan apakah SH pada pasien disebabkan oleh mutasi spontan atau diturunkan secara resesif. Sebelum pasien dan orangtua diperiksa genetika molekular.

Sferositosis herediter diklasifikasikan menjadi ringan, sedang, dan berat atas dasar kadar hemoglobin, retikulosit dan bilirubin (Tabel 1). ${ }^{8,9}$ Gangguan tumbuh kembang serta struktur wajah seperti pada pasien talasemia, dapat dijumpai pada $\mathrm{SH}$ berat. ${ }^{2}$

Proses hemolisis pada SH terjadi ekstravaskular yaitu di limpa sehingga ukuran limpa dapat menjadi indikator derajat anemia pasien $\mathrm{SH} .{ }^{9}$ Splenomegali

Tabel 2. Parameter diagnostik sferositosis herediter ${ }^{9}$

\begin{tabular}{ll}
\hline \multicolumn{1}{c}{ Parameter } & \multicolumn{1}{c}{ Hasil } \\
\hline Pemeriksaan fisis & Spenomegali \\
Darah tepi lengkap & Hb $\downarrow, \mathrm{MCV} \downarrow, \mathrm{MCHC} \uparrow, \mathrm{RDW} \uparrow$, \\
& retikulosit $\uparrow$ \\
Gambaran darah tepi & Morfologi abnormal: sferosit \\
Uji Coombs & Negatif \\
Proses hemolitik & Bilirubin $\uparrow$, retikulositosis \\
\hline
\end{tabular}




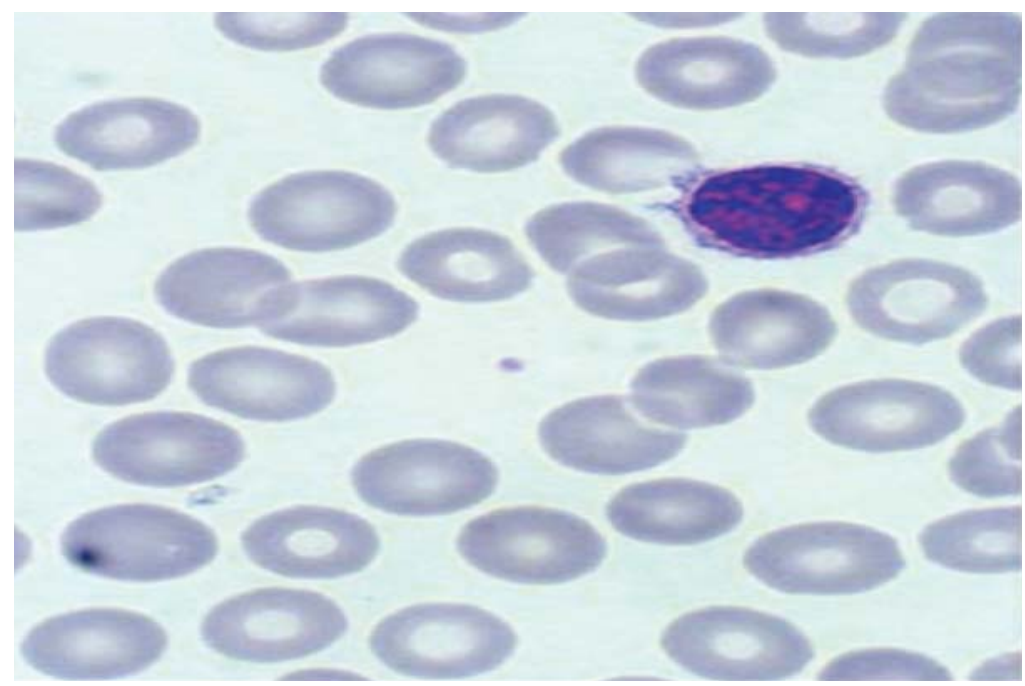

A. Sel darah merah normal

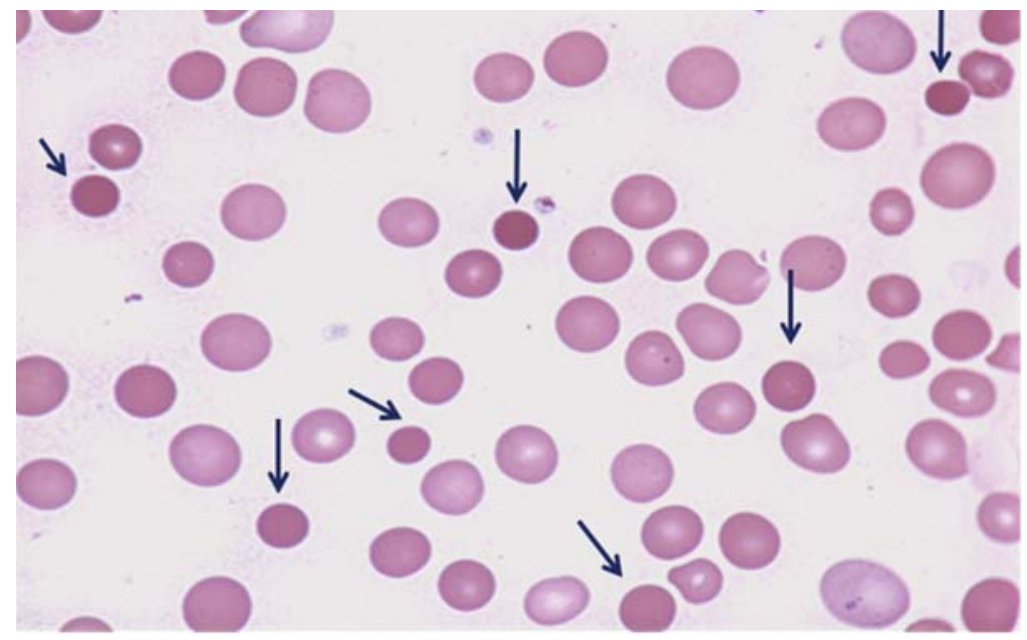

B. Sel darah merah yang menunjukkan sferositosis

Gambar 2. Gambaran darah tepi

dijumpai pada semua kasus $\mathrm{SH}$, namun pada umumnya baru ditemukan pada anak besar dan dewasa. ${ }^{2}$ Usia eritrosit pada SH menjadi lebih pendek, sehingga jumlah eritrosit yang beredar menurun. Kadar eritropoietin akan meningkat dan merangsang aktivitas sumsum tulang untuk memproduksi eritrosit. Aktivitas sumsum tulang yang meningkat ditandai dengan peningkatan jumlah retikulosit dalam darah.10 Pada pemecahan hemoglobin terbentuk bilirubin indirek. Kadar bilirubin indirek lebih dari $3 \mathrm{mg} / \mathrm{dL}$ menunjukkan hemolisis yang berat. ${ }^{9}$ Enam puluh lima persen pasien $\mathrm{SH}$ mengalami ikterus neonatorum dan beberapa kasus di antaranya memerlukan transfusi tukar. ${ }^{11}$ Pasien ini menunjukkan gejala klinis anemia 
hemolitik yang sesuai dengan $\mathrm{SH}$ yaitu pucat, riwayat ikterus neonatorum, dan splenomegali. Gejala tersebut sesuai dengan laporan Mariani dkk, ${ }^{12}$ bahwa anemia, splenomegali dan ikterus neonatorum merupakan kelainan yang paling sering ditemukan pada $\mathrm{SH}$.

Pemeriksaan laboratorium awal yang dilakukan pada anemia meliputi pemeriksaan darah tepi lengkap termasuk retikulosit. ${ }^{1}$ Anemia dengan peningkatan retikulosit sering ditemukan pada anemia hemolitik termasuk $\mathrm{SH}$. Derajat anemia pada $\mathrm{SH}$ bervariasi mulai dari ringan (Hb 11-15 g/dL) sampai berat ( $\mathrm{Hb} 6-8 \mathrm{~g} /$ dL). Nilai MCHC meningkat hingga 35\%-38\% pada sebagian besar pasien $\mathrm{SH} .{ }^{1,2}$ Kombinasi pemeriksaan MCHC $>35 \mathrm{~g} / \mathrm{dL}$ dan Red cell Distribution Width (RDW) $>14 \%$ mempunyai sensitivitas 63\% dan spesifisitas hingga $100 \%$ (Tabel 2). ${ }^{13}$ Pada gambaran darah tepi $\mathrm{SH}$ ditemukan sferosit dalam jumlah banyak. Sferosit adalah sel eritrosit berbentuk bulat, tanpa central pallor dengan ukuran yang lebih kecil daripada eritrosit normal (Gambar 2). ${ }^{2}$

Pemeriksaan penunjang yang dapat digunakan adalah uji fragilitas osmotik (resistensi $\mathrm{NaCl}$ ). Fragilitas eritrosit pasien $\mathrm{SH}$ akan meningkat, sehingga jumlah sel yang lisis akan lebih banyak dibandingkan kontrol. ${ }^{1,2}$ Uji fragilitas eritrosit kurang spesifik karena akan menujukkan hasil yang positif pada kelainan eritrosit lainnya seperti eliptositosis herediter, dan dapat negatif pada pasien $\mathrm{SH}$ dengan retikulosit yang tinggi. ${ }^{1,2,9}$ Pemeriksaan lain yang digunakan untuk $\mathrm{SH}$ adalah cryohemolysis test, osmotic gradient ektacytometry test dan eosin-5 maleimide (EMA) binding test dengan nilai prediktif yang lebih tinggi dibandingkan dengan uji fragilitas osmotik. ${ }^{9}$ Identifikasi protein membran yang mengalami defisiensi akan membantu menegakkan diagnosis SH. Metode yang digunakan adalah elektroforesis dengan SDS-PAGE (sodium dedocyl sulfate-polyacrylamide gel). ${ }^{9}$ Di Eropa dan Amerika Serikat, abnormalitas protein membran eritrosit terdeteksi pada lebih dari 80\% kasus SH. Empat jenis kelainan protein membran yang terdeteksi adalah defisiensi ankirin dan spektrin, defisiensi spektrin saja, reduksi band 3 protein dan palidin. ${ }^{11}$

Pada awalnya pasien ini diduga menderita talasemia karena ditemukan pucat, organomegali dengan kadar hemoglobin yang rendah, dan RDW yang meningkat namun $\mathrm{MCV}, \mathrm{MCH}$ dan $\mathrm{MCHC}$ dalam batas normal. Pemeriksaan ke arah kelainan membran eritrosit dilakukan karena banyak ditemukan sferosit pada gambaran darah tepi, dan uji Coombs yang negatif, dan hasil pemeriksaan fragilitas osmotik positif serta terdapat defisiensi spektrin alfa pada pemeriksaan analisis protein membran eritrosit. Aspirasi sumsum tulang tidak rutin dikerjakan untuk mendiagnosis $\mathrm{SH}$, namun pada beberapa kasus dengan anemia berat aspirasi sumsum tulang dilakukan untuk menyingkirkan penyebab anemia lainnya. Pada pasien pernah didapatkan anemia berat sehingga aspirasi sumsum tulang dilakukan untuk menyingkirkan kemungkinan penyebab anemia lainnya.

Tala laksana SH secara garis besar sama dengan anemia hemolitik pada umumnya. Asam folat diberikan pada pasien anemia hemolitik kronis untuk merangsang eritropoiesis, namun tidak ada bukti kuat yang mendukung suplementasi asam folat pada SH. ${ }^{9}$ Walaupun demikian, asam folat dibutuhkan pada pasien $\mathrm{SH}$ dengan anemia berat mengingat kemungkingan defisiensi pada keadaan tersebut. ${ }^{9,14}$ Dosis yang direkomendasikan pada $\mathrm{SH}$ dengan anemia sedang sampai berat $2,5 \mathrm{mg} /$ hari untuk anak di bawah 5 tahun dan $5 \mathrm{mg} /$ hari untuk usia lebih tua. ${ }^{9}$ Transfusi rutin diberikan pada pasien $\mathrm{SH}$ dengan anemia berat, krisis aplasia, dan hipersplenisme. ${ }^{1}$ Pasien pernah mengalami anemia berat sehingga membutuhkan transfusi darah merah, namun dalam pengamatan selanjutnya kadar Hb pasien berkisar 8-9 g/dL, sehingga tidak dilakukan transfusi secara rutin.

Kontrol teratur bagi pasien SH sangat penting, demikian pula edukasi pada orangtua serta tindak lanjut terhadap keadaan umum, pertumbuhan, ukuran limpa dan pemantauan terhadap komplikasi. Hemolisis kronis yang terjadi pada SH merupakan faktor risiko terjadinya kolelitiasis. ${ }^{15}$ Kolelitiasis ditemukan pada 21\%-63\% kasus SH dan sekitar $50 \%$ pasien tidak menunjukkan gejala. Usia termuda ditemukan kolelitiasis pada $\mathrm{SH}$ adalah 4-5 tahun., ${ }^{9}$ Penelitian di Italia mendapatkan kolelitiasis 8\% dari 468 anak dengan SH berusia kurang dari 11 tahun. ${ }^{16}$ Pemeriksaan ultrasonografi secara teratur sebaiknya mulai dilakukan setelah usia 5 tahun, kemudian berkala setiap 3-5 tahun atau ketika ditemukan gejala. ${ }^{9,15}$ Anak dengan kolelitiasis harus menjalani kolesistektomi dan splenektomi untuk menurunkan angka kejadian infeksi. ${ }^{9}$ Komplikasi lain yang dapat terjadi adalah hemosiderosis atau hemokromatosis akibat transfusi darah berulang. Oleh karena itu pemeriksaan berkala kadar besi harus dilakukan terutama pada $\mathrm{SH}$ berat. Saat ini pasien tidak mengalami iron overload sehingga terapi kelasi besi belum diperlukan. 
Pada pasien SH berat juga dipertimbangkan splenektomi. Keputusan untuk splenektomi sebaiknya dipikirkan dengan hati-hati mengingat risiko infeksi yang tinggi terutama pada tahun pertama pascasplenektomi. Vaksinasi pneumokokus pra-splenektomi dan pemberian profilaksis penisilin seumur hidup pasca- splenektomi telah menjadi kebijakan di Inggris. ${ }^{17,18}$ Namun hal itu tidak mengurangi risiko infeksi yang dapat terjadi. ${ }^{19}$ Tidak ada penelitian yang menunjukkan keuntungan pemberian antibiotik profilaksis seumur hidup dibandingkan dengan pemberian selama dua tahun untuk orang dewasa dan lima tahun untuk anak. ${ }^{20}$ Pemberian antibiotik profilaksis harus tetap mempertimbangkan resistensi penisilin terhadap Pneumococcus. Splenektomi akan menguntungkan bagi pasien dengan anemia berat dan transfusi eritrosit rutin. Waktu yang tepat menurut Gallagher mulai usia 6 tahun hingga menjelang pubertas, namun jika dibutuhkan lebih dini sebaiknya tidak kurang dari usia 3 tahun. ${ }^{4}$

Pasien ini termasuk dalam SH sedang, dan tidak membutuhkan transfusi rutin, sehingga splenektomi belum diperlukan pada saat ini. Sebagaimana pada sebagian besar pasien $\mathrm{SH}$, prognosis pasien baik karena anemia yang dialami masih dapat dikompensasi oleh sumsum tulang.

\section{Daftar Pustaka}

1. Vega R, Syah S. Hereditary spherocytosis. Pediatr Rev 2004;25:168-72.

2. Gallagher PG. Red cell membrane disorders. Hematology 2005;1:13-8.

3. Del Miraglia GE, Nobili B, Francese M, D’Urso L, Iolascon A, Perrota S, dkk. Clinical and molecular evaluation of non-dominant hereditary spherocytosis. Br J Haematol 2001;112:42-7.

4. Gallagher PG, Lux SE. Disorders of the erythrocyte membrane. Dalam: Nathan DG, Orkin SH, Ginsburg D, Look AT, penyunting. Nathan and Oski's hematology of infancy and childhood. Philadelphia: Saunders Elsevier; 2003.h.561-684.

5. Eber S, Lux SE. Hereditary spherocytosis: defects in protein that connect the membrane skeleton to the lipid bilayer. Semin Hematol 2004;41:118-41.

6. Aster JC. Red blood cell and bleeding disorders. Dalam: Kumar V, Abbas AK, Fausto N, penyunting. Robbins and Cotran : Pathologic basis of disease. Edisi ke-7. Philadelphia: Elsevier Saunders; 2005.h.626

7. Yawata Y, Kanzaki A, Yawata A, Doerfler W, Ozcan R, Eber SW. Characteristic features of the genotype and phenotype of hereditary spherocytosis in the Japanese population. Int J Hematol 2000;71:118-35.

8. Iolascon A, Perrotta S, Tavano R, del Miraglia GE. Hereditary spherocytosis in newborn. Dalam: Bellanti JA, Bracci R, Prindull G, Xanthao M, penyunting. Neonatal hematology and immunology. Edisi ke-3. New York: Elsevier; 1997.h. 197-202.

9. Bolton-Maggs PH, Stevens RF, Dodd NJ, Lamont G, Tittensor P, King MJ. Guidelines for the diagnosis and management of hereditary spherocytosis. Br J Haematol 2004; 126:455-74.

10. Segel GB. Definitions and classification of hemolytic anemias. Dalam: Kliegman RM, Behrman RE, Jenson $\mathrm{HB}$, Stanton BF, penyunting. Nelson textbook of pediatrics. Edisi ke-18. Philadelphia: Saunders Elsevier; 2007. h. 2018-20.

11. Iolascon A, del Miraglia GE, Perrotta S, Alloisio N, Morle L, Delaunay J. Hereditary spherocytosis: from clinical to molecular defects. Hematologica 1998;83:240-57.

12. Mariani M, Barcellini W, Vercellati C, Macello AP, Fermo E, Pedotti P, dkk. Haematologica 2008;93:1310-7

13. Michaels LA, Cohen AR, Zhao H, Raphael RI, Manno CS. J Pediatr 1997;130:957-60.

14. Werner EJ. Megaloblastic anemia and disorders of cobalamin and folat metabolism. Dalam: Arceci R, Hann IM, Hoffbrand AV, Smith OP, penyunting. Pediatric hematology. Edisi ke-3. Massachusetts: Blackwell Publishing; 2006.h.105-29.

15. Segel GB. Hereditary spherocytosis. Kliegman RM, Behrman RE, Jenson HB, Stanton BF. Nelson textbook of pediatrics. Edisi-18. Philadelphia: Saunders Elsevier; 2007.h.2020-3.

16. Pinto L, Iolascon A, del Miraglia GE, Matarese SMR, Nobili $\mathrm{B}$, Perrota $\mathrm{S}$. The Italian survey on hereditary spherocytosis. Int J Pediatr Hematol Oncol 1995;2:43-7.

17. Davies KS, Walport MJ, Beynon HL. Long-term management after splenectomy. Consider prophylaxis in systematic lupus erythematosus. Br Med J 1994; 308:33.

18. BCSH. Guidelines for the prevention and treatment of infection in patients with an absent or dysfunctional spleen: Working party of the British Committee for Standards in Haematology Clinical Haematology Task Force. Br Med J 1996;312:430-4.

19. Evans DI. Post-splenectomy sepsis 10 years or more after 
operation. J Clin Pathol 1985;38:309-11.

20. Beytout J, Tournilhac O, Laurichesse H. Antibiotic prophylaxis in splenectomized adults. Presse Med 2003;32:17-9. 